\title{
Effects of resource availability and bacterivory on leucine incorporation in different groups of freshwater bacterioplankton, assessed using microautoradiography
}

\author{
Karel Horňák ${ }^{1,2, *}$, Jan Jezbera' ${ }^{1,2}$, Jiří Nedoma ${ }^{1}{ }$ Josep M. Gasol $^{3}$, Karel Šimek ${ }^{1,2}$ \\ ${ }^{1}$ Biology Centre of the Academy of Sciences of the Czech Republic, Institute of Hydrobiology, Na Sádkách 7, \\ 37005 České Budějovice, Czech Republic \\ ${ }^{2}$ Faculty of Biological Sciences, University of South Bohemia, Branišovská 31, 37005 České Budějovice, Czech Republic \\ ${ }^{3}$ Institute of Marine Sciences, CMIMA, Pg. Marítim de la Barceloneta 37-49, 08003 Barcelona, Spain
}

\begin{abstract}
We examined changes in the phylogenetic structure and leucine incorporation of bacterioplankton assemblages exposed to variable levels of available resources and bacterivory in a freshwater reservoir. Fluorescence in situ hybridization (FISH) combined with microautoradiography was used to determine bacterial phylogenetic affiliations and the proportions of cells incorporating leucine. Grazing-free and grazing-enhanced treatments were incubated in both P-limited and P-rich areas of the reservoir using dialysis bags, and bottle treatments with and without $\mathrm{P}$ enrichment. $\beta$-Proteobacteria, mainly the R-BT065 cluster (subcluster of Rhodoferax sp. BAL47), became the dominant leucine-active bacteria in all treatments. Proportions of active cells belonging to R-BT065 phylotypes considerably increased under conditions of enhanced protistan grazing and phosphorus availability. In contrast, proportions of cells from the Sphingobacteria/Flavobacteria group usually decreased and exhibited very low rates of leucine uptake. $\gamma$-Proteobacteria was the least abundant but nevertheless a highly active part of the assemblage. Phosphorus addition supported incorporation of leucine by all bacterial groups. Although highly vulnerable to predation, only R-BT065 cells exhibited marked increases in both relative abundance within the bacterial community and in proportions of active cells. The phylogenetic composition and leucine-uptake of bacterioplankton was more markedly affected by resource availability than by grazing pressure, which only had a strong effect on the dynamics of R-BT065 bacteria within the P-limited area of the reservoir.
\end{abstract}

KEY WORDS: Reservoir bacteria - Resource availability · Bacterivory · Leucine incorporation • Bacterioplankton structure $\cdot$ Bacterioplankton function

\section{INTRODUCTION}

Bacterioplankton assemblages are highly diverse in both phylogenetic and metabolic terms (e.g. Troussellier et al. 2002). Despite the increasing number of studies describing the phylogenetic structure of bacterial assemblages in various aquatic environments (e.g. Pernthaler \& Amann 2005), information on the metabolic capabilities and biogeochemical functions of specific bacterial groups remains scant. Traditional cultivation techniques only provide relevant information on the metabolic capabilities of a very restricted proportion of total bacteria. The vast majority of bacteria have not yet been cultured, mostly because of inappropriate culture conditions (Amann et al. 1995). Culture-independent methods that directly link the structure and function of a given bacterial group or phylotype, such as the recently developed fluorescence in situ hybridization (FISH) in combination with microautoradiography (Lee et al. 1999, Cottrell \& 
Kirchman 2000, Ouverney \& Fuhrman 2000, Ito et al. 2002), are thus very useful. In this procedure, the phylogenetic identity of an organism is determined by FISH, and its function is determined by microautoradiography following the active uptake of a suitable radiolabelled substrate.

Bacterioplankton assemblages in freshwater ecosystems are regulated by various types of factors, e.g. resource availability related to environmental heterogeneity, predation, viral lysis, and interactions with other components of aquatic food webs (e.g. Thingstad \& Lignell 1997, Fuhrman 1999). Typically, bacteria live in a nutrient-deficient environment, determined by the amount and composition of available organic and inorganic substrates, i.e. phosphorus in freshwater (e.g. Pace \& Cole 1996). Furthermore, growth rates of bacteria appear to vary significantly both at the single cell level and among different phylogenetic groups (Kirchman 2002). The enrichment of a deficient substrate may also only support the growth of specific groups of bacteria (e.g. Vrede 1999).

Bacteria play an important role in the degradation of organic matter (Azam et al. 1983). Degradation of organic matter is usually studied using bulk activity parameters of the whole bacterial community; however, it is known that the uptake and utilization of various substrates (Eilers et al. 2000) and metabolic activity of individual cells (e.g. Karner \& Fuhrman 1997) can vary substantially among bacteria. Thus, the composition of available substrates or artificial nutrient addition may influence the growth, metabolic activity, and composition of bacterial communities by differently affecting specific bacterial subpopulations within the whole assemblage.

Heterotrophic nanoflagellates (HNF) are commonly found to be the major bacterial consumers (e.g. Sanders et al. 1989, Hahn \& Höfle 2001, Jürgens \& Matz 2002), regulating not only bacterial abundance but also the morphologic and phylogenetic structure of bacterial assemblages (e.g. Šimek et al. 1997). HNF may specifically select for large (Chrzanowski \& Šimek 1990) or the most active cells within a community (del Giorgio et al. 1996a). Additionally, intense grazing pressure may induce the development of various grazing-resistant morphotypes, mainly filaments and flocs (Jürgens \& Güde 1994, Šimek et al. 2001, 2003). Large metazooplankton predators, e.g. Daphnia spp., may also affect the composition and morphology of bacterial assemblages (e.g. Langenheder \& Jürgens 2001).

The goal of this study was to determine changes in the phylogenetic structure and active incorporation of leucine of major bacterioplankton groups exposed to variable levels of resource availability and predation pressure within the canyon-shaped Římov reser- voir (Czech Republic). We intended to determine the groups of bacteria specifically engaged in the production processes within the community (leucine incorporation), and to identify the bacterial groups contributing the most to bulk production of the assemblage.

\section{MATERIALS AND METHODS}

Experimental design. The experiment was conducted from 19 to 23 May 2003 in the canyon-shaped Rímov reservoir (South Bohemia; $470 \mathrm{~m}$ above sea level ${ }_{i}$ area $2.06 \mathrm{~km}^{2}$; volume $34.5 \times 10^{6} \mathrm{~m}^{3}$; length $13.5 \mathrm{~km}$; max. depth $43 \mathrm{~m}_{\text {; }}$ mean depth $16.5 \mathrm{~m}$; mean retention time $100 \mathrm{~d}_{\text {i dimictic, meso-eutrophic) at } 2}$ experimental sites that markedly differed in phosphorus availability. The first site was located close to the dam of the reservoir (Stn Dam: dissolved reactive P $0.12 \mu \mathrm{M} \mathrm{l}^{-1}$ ), and the second in the middle of the reser-

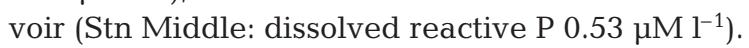

On 19 May 2003, 40 l of water were collected from each station with a 21 Friedinger sampler from a depth of $\sim 0.5 \mathrm{~m}$, and transferred into a plastic container. Subsequently, the water was size-fractionated through 5 and $0.8 \mu \mathrm{m}$ polycarbonate filters (Osmonics, Poretics) to produce the following size fractions: $\mathrm{a}<5 \mu \mathrm{m}$ treatment, containing bacteria, HNF and small algae; and a $<0.8 \mu \mathrm{m}$ treatment, containing bacteria only.

To alter resource availability, the 2 size fractions $(<0.8$ and $<5 \mu \mathrm{m})$ were incubated in (1) dialysis bags with a continuous supply of nutrients from the ambient environment (each containing $\sim 1.8 \mathrm{l}$ of sample; diameter of dialysis tubes $75 \mathrm{~mm}$; molecular weight cutoff

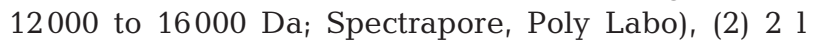
glass bottles non-penetrable to nutrients, and (3) 21 glass bottles enriched with orthophosphate (final concentration $2 \mu \mathrm{M} \mathrm{P} \mathrm{l}^{-1}$, enrichment factors 16.3 and 3.8 for Stns Dam and Middle, respectively). Prior to the experiment, the dialysis bags were twice incubated in Milli-Q water at $70^{\circ} \mathrm{C}$ for $30 \mathrm{~min}$ and subsequently washed with Milli-Q water. The treatments were incubated in the reservoir for $4 \mathrm{~d}$ at a depth of $0.5 \mathrm{~m}$. All treatments were sampled daily (at $0,24,48,72$, and $96 \mathrm{~h}$ ) for further analyses (except for leucine incorporation and microautoradiography). Additionally, unfiltered reservoir water that contained all planktonic organisms present at each study site was sampled daily. All treatments were incubated in duplicate.

Bacterial abundance and leucine incorporation. Samples were preserved in prefiltered formaldehyde (final concentration $2 \%$ ), and 1 to $2 \mathrm{ml}$ samples were stained with DAPI (final concentration $0.2 \% \mathrm{wt} / \mathrm{vol}$ ) for $4 \mathrm{~min}$ and then filtered through $0.2 \mu \mathrm{m}$ black polycarbonate filters (Osmonics). Bacteria were enumerated 
using epifluorescence microscopy (BX-60, Olympus). Samples for leucine incorporation were taken at 0,48 , 72 , and $96 \mathrm{~h}$. Incorporation of $\mathrm{L}-\left[{ }^{14} \mathrm{C}\right]$-leucine was assessed. The substrate was added to each sample (specific activity $6.4 \mathrm{TBq} \mathrm{mmol}^{-1}$; final concentration $10 \mathrm{nmol} \mathrm{l}^{-1}$; MP Biomedicals), and samples were incubated at in situ temperature in darkness for $30 \mathrm{~min}$ before preservation in prefiltered formaldehyde (final concentration $2 \% \mathrm{vol} / \mathrm{vol}$ ). Subsequently, samples were filtered through $0.2 \mu \mathrm{m}$ polycarbonate filters (Osmonics) and rinsed 10 times with $1 \mathrm{ml}$ of ice-cold $5 \%$ trichloroacetic acid (TCA). Replicate blanks preserved in $2 \%$ formaldehyde were processed in parallel. Furthermore, filters were transferred into scintillation vials followed by the addition of scintillation cocktail. The amount of incorporated leucine was expressed in $\mathrm{nmol} \mathrm{l}^{-1} \mathrm{~h}^{-1}$.

Microautoradiography and FISH. A combination of catalyzed reporter deposition-fluorescence in situ hybridization (CARD-FISH) and microautoradiography (Teira et al. 2004) was used to determine the phylogenetic affiliation and proportions of metabolically active bacteria. Samples for microautoradiography were taken at 0,48 , and $96 \mathrm{~h}$. Samples of $5 \mathrm{ml}$ were incubated with a tracer concentration of L- $\left[{ }^{3} \mathrm{H}\right]$-leucine (specific activity $37 \mathrm{Ci} \mathrm{mmol}{ }^{-1}$; final concentration $10 \mathrm{nmol} \mathrm{l}^{-1}$; MP Biomedicals) for $1 \mathrm{~h}$ at in situ temperature in darkness. Controls were killed with $0.2 \mu \mathrm{m}$ prefiltered formaldehyde (final concentration $2 \%$ ), $30 \mathrm{~min}$ before the addition of leucine. Incubations of live samples were terminated by addition of prefiltered formaldehyde (final concentration $2 \%$ ). Samples were fixed overnight at $4^{\circ} \mathrm{C}$ in darkness, filtered through $0.2 \mu \mathrm{m}$ polycarbonate filters (Osmonics) supported by $0.45 \mu \mathrm{m}$ cellulose acetate filters (Osmonics), rinsed with Milli-Q water, and air-dried and stored at $-20^{\circ} \mathrm{C}$ until further processing.

Bacteria on filters were then incubated with lysozyme and achromopeptidase (Sekar et al. 2003). The relative proportions of different bacterial groups were determined using the horseradish peroxidase-labelled (HRP) oligonucleotide probes (biomers.net) EUB338 to target most Bacteria (EUB), BET42a and GAM42a to target $\beta$ - and $\gamma$-Proteobacteria (BET and GAM, respectively), CF319a to target the Sphingobacteria/ Flavobacteria group of Bacteroidetes (CF), R-BT065 to target the R-BT065 subcluster of Rhodoferax sp. BAL47 (R-BT, Zwart et al. 2002; for phylogenetic affiliation see Šimek et al. 2005), and HGC69a to target Actinobacteria (Sekar et al. 2003). To avoid mismatch hybridization, HRP-labelled BET42a probe was mixed with the same amount of non-labelled GAM42a probe during hybridization and vice versa. After hybridization, performed at $35^{\circ} \mathrm{C}$ for $2 \mathrm{~h}$ (a formamide concentration of $55 \%$ [vol/vol] was used for all probes except
HGC69a [30\%]), the filters were incubated in washing buffer at $37^{\circ} \mathrm{C}$ for $10 \mathrm{~min}$, and signal amplification with ALEXA $_{488}$-labelled tyramide (final concentration $0.1 \mathrm{mg} \mathrm{ml}^{-1}$, Molecular Probes) was carried out.

Slides were then coated with photographic emulsion (type NTB-2, Kodak) in complete darkness, melted in a water bath at $44^{\circ} \mathrm{C}$ for $45 \mathrm{~min}$, mixed with a $1: 1$ ratio of $0.2 \%$ (wt/vol) low melting-point agarose (Sigma), and dried on an ice-cold aluminum plate for 5 min. Filters with hybridized bacteria were then transferred upside-down onto the slides coated with emulsion under a $15 \mathrm{~W}$ lamp equipped with a safelight filter (Type No. 2, Kodak). Slides were placed in a light-tight box with silica gel and maintained at $4{ }^{\circ} \mathrm{C}$ during exposure $(72 \mathrm{~h})$. The emulsion was developed and fixed following the manufacturer's instructions and dried in a dessiccator overnight. Subsequently, filters attached to the emulsion were moistened with $80 \%$ (vol/vol) ethanol and peeled off. Cells were stained with DAPI (final concentration $1 \mu \mathrm{g} \mathrm{m} \mathrm{m}^{-1}$ ) mixed with 4 parts Citifluor (Citifluor) and 1 part Vectashield (Vector Laboratories). The relative proportions of various groups of bacteria were enumerated by epifluorescence microscopy (PROVIS AX-70, Olympus). The presence/absence of silver grains connected with cells was determined via light transmission. Bacterial cells connected with 2 or more silver grains were considered as actively taking up the radiolabelled compound (Teira et al. 2004). At least 500 DAPI-stained cells were counted per sample.

Flow cytometry. Samples of $2 \mathrm{ml}$ were fixed in a mixture of fresh paraformaldehyde and glutaraldehyde (final concentration 1 and $0.05 \%$, respectively) at room temperature for $10 \mathrm{~min}$, then frozen in liquid nitrogen and stored at $-80^{\circ} \mathrm{C}$ (Gasol et al. 1999). After thawing, samples were stained with SYTO 13 (10-times diluted

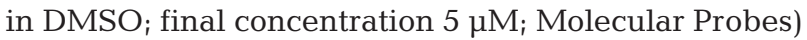
in the dark for $5 \mathrm{~min}$, and subsequently run through a flow cytometer (FACSCalibur, Becton Dickinson) under the low speed mode $\left(\sim 9 \mu \mathrm{min}^{-1}\right.$; rate of particle passage $<1000$ events $\mathrm{s}^{-1}$ ). Yellow-green latex beads (diameter $1 \mu \mathrm{m}_{i} \sim 10^{6}$ beads $\mathrm{ml}^{-1}$; Polysciences) were added as an internal standard. The concentration of Polysciences beads was calibrated prior to analysis using the TruCount beads solution (Becton Dickinson, further details in del Giorgio et al. 1996b). To separate bacteria with high nucleic acid content (HNA) from cytometric noise, a $90^{\circ}$ side-light scatter vs. green fluorescence plot was used (for details see Gasol \& del Giorgio 2000). Results were expressed as \% of HNA cells in total bacterial cells.

Abundance of flagellates. HNF were enumerated in the $<5 \mu \mathrm{m}$ and unfiltered treatments at each time point. Samples were prefixed with $0.5 \%$ alkaline Lugol's solution, fixed in prefiltered formaldehyde (final concentra- 
tion $2 \%$ ), and finally cleared with several drops of a $3 \%$ solution of sodium thiosulphate (Sherr \& Sherr 1993). To determine the abundance of HNF, samples of 5 to $10 \mathrm{ml}$ were filtered through $1 \mu \mathrm{m}$ black polycarbonate filters (Osmonics), and at least 100 DAPI-stained HNF were inspected and enumerated per sample (details in Šimek et al. 2003) using epifluorescence microscopy (PROVIS AX-70, Olympus).

Statistical analysis. Data on the relative proportions of different phylogenetic groups (as \% of DAPI counts) and proportions of cells incorporating leucine (as \% of hybridized cells) were normalized using arcsine transformation. A 2-way ANOVA was used to test the effects of size fractionation (<0.8 vs. $<5 \mu \mathrm{m})$ and type of incubation (dialysis bags, and bottle treatments with and without $\mathrm{P}$ enrichment) on the phylogenetic structure and leucine incorporation of bacteria. ANOVAs were performed independently for time intervals $t_{48}$ and $t_{96}$. Replicate data $(n=2)$ were available for every sample. Tukey's multiple comparison post-hoc test was applied to pair-wise comparisons of treatments (for comparisons of both the relative proportions of bacterial groups and percentage of cells incorporating leucine). All statistics were performed using GraphPad Prism (GraphPad Software).

\section{RESULTS}

\section{Abundance of bacteria and HNF}

In almost all cases, bacterial abundance was lower at Stn Middle than at Stn Dam (Fig. 1). In all grazer-free treatments $(<0.8 \mu \mathrm{m}$ size fraction), the abundance of bacteria increased dramatically over time, peaking mostly at $t_{72}$, with maximum values recorded in dialysis bag incubations. Interestingly, in bottle treatments enriched with $\mathrm{P}$ incubated at Stn Dam, bacterial

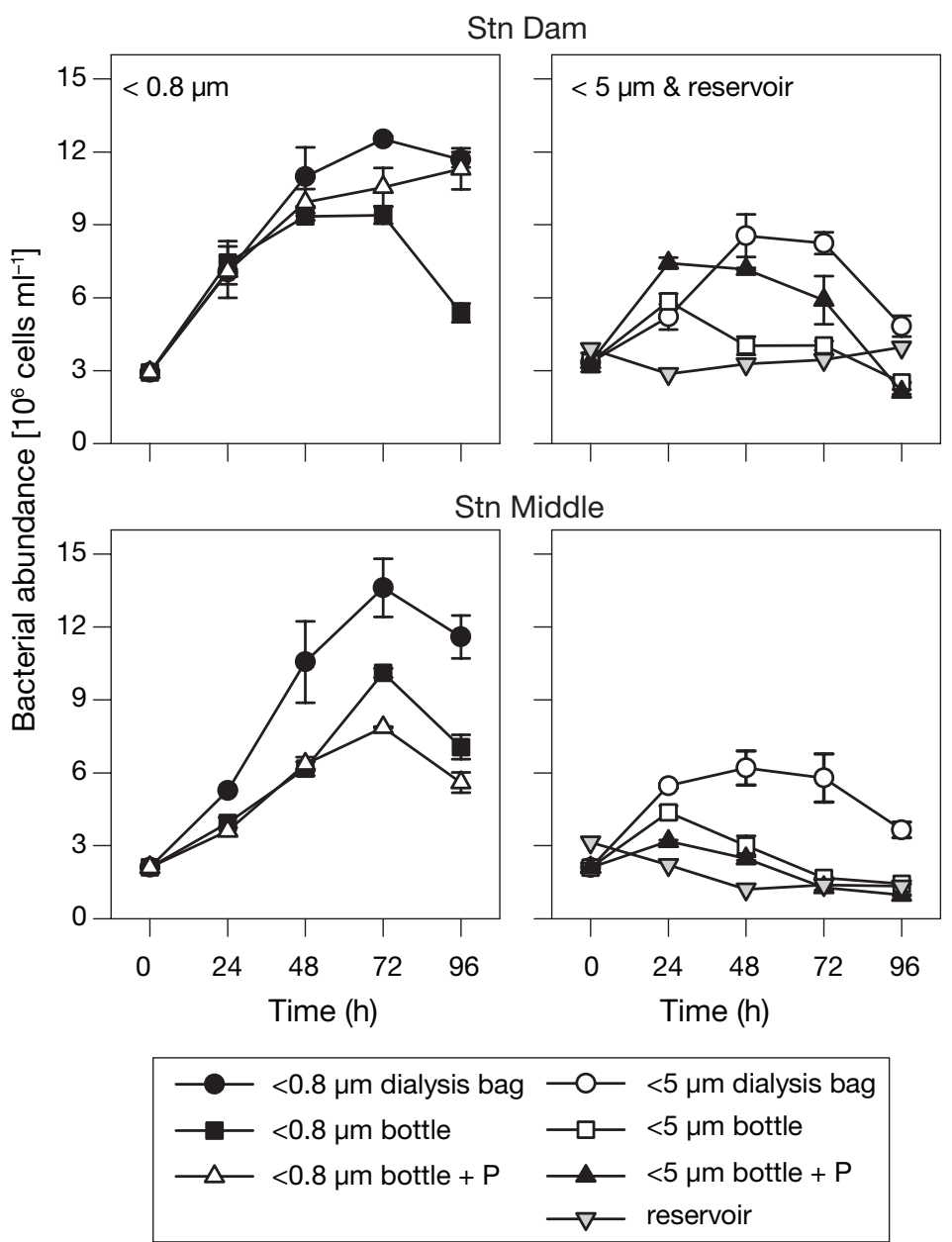

Fig. 1. Temporal changes in bacterial abundances in different treatments (dialysis bag, bottle treatments with and without P enrichment, unfiltered reservoir samples) at both experimental sites (Stns Dam and Middle). Values are mean of duplicates. Error bars $= \pm \mathrm{SD}$ growth continued until the end of experiment (Fig. 1). Bacterial abundance was markedly lower in the unfiltered treatments of reservoir water, with only minor changes observed at either station during incubation.

In treatments with enhanced bacterivory $(<5 \mu \mathrm{m}$ size fraction) and high abundances of HNF (Table 1), bacterial abundance was considerably lower than in the corresponding $<0.8 \mu \mathrm{m}$ treatments. In most $<5 \mu \mathrm{m}$

Table 1. Abundance of heterotrophic nanoflagellates $\left(\mathrm{HNF}_{;} 10^{3} \mathrm{ml}^{-1}\right.$ ) in $<5 \mu \mathrm{m}$ size fractions incubated in dialysis bags, bottles with and without $\mathrm{P}$ enrichment, and in unfiltered treatments of reservoir water at $t_{0}, t_{48}$ and $t_{96}$. Values are mean of duplicates

\begin{tabular}{|lccccccccccccc}
\hline \multirow{2}{*}{ Stn } & \multicolumn{3}{c}{ Dialysis bag } & \multicolumn{3}{c}{ Bottle } & \multicolumn{3}{c}{ Bottle + P } & \multicolumn{3}{c}{ Reservoir } \\
& $t_{0}$ & $t_{48}$ & $t_{96}$ & $t_{0}$ & $t_{48}$ & $t_{96}$ & $t_{0}$ & $t_{48}$ & $t_{96}$ & $t_{0}$ & $t_{48}$ & $t_{96}$ \\
\hline Dam & 0.13 & 3.41 & 24.43 & 0.13 & 15.12 & 13.05 & 0.13 & 20.20 & 12.04 & 0.16 & 0.70 & 0.40 \\
Middle & 0.11 & 3.46 & 17.86 & 0.11 & 20.39 & 12.42 & 0.11 & 20.78 & 5.89 & 0.18 & 0.09 & 0.29 \\
\hline
\end{tabular}




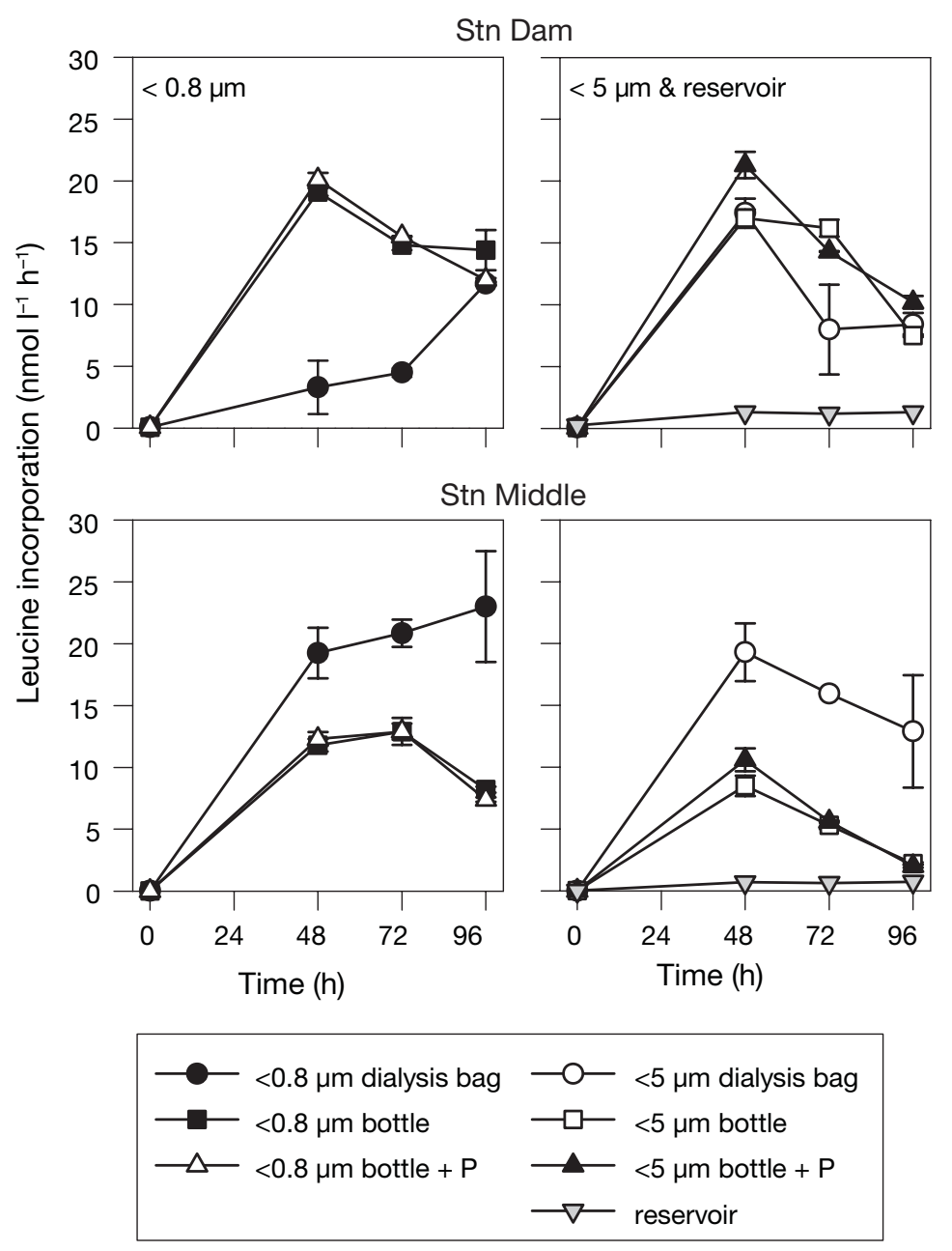

Fig. 2. Time-course of rates of bacterial leucine incorporation in different treatments (dialysis bag, bottle treatments with and without P enrichment, unfiltered reservoir samples) at both experimental sites (Stns Dam and Middle). Values are mean of duplicates. Error bars $= \pm \mathrm{SD}$

pared with other treatments, with no significant changes observed during the experiment (Fig. 2). In all other treatments, leucine incorporation usually ranged between 3 and $23 \mathrm{nmol}$ leucine $\mathrm{l}^{-1} \mathrm{~h}^{-1}$. At Stn Middle, bacteria in the $<0.8$ and $<5 \mu \mathrm{m}$ treatments incubated in dialysis bags showed higher rates of leucine incorporation (13 to 23 nmol leucine $\mathrm{l}^{-1} \mathrm{~h}^{-1}$ between $t_{48}$ and $t_{96}$ ) than bacteria incubated in either of the bottle treatments. At Stn Dam, the highest rates of leucine incorporation were measured in the P-enriched bottle treatments of both size fractions and in the $<5 \mu \mathrm{m}$ treatments incubated in bottles without $\mathrm{P}$ enrichment.

\section{Bacterial community composition}

In general, the relative proportions of bacterial phylogenetic groups were very similar at Stns Dam and Middle (Table 2). Due to very low proportions of Actinobacteria (typically $<3 \%$, data not shown), microautoradiography was not applied to this group.

The bacterioplankton assemblage was dominated by $\beta$-Proteobacteria (BET) at both study sites, which usually accounted for between 24 and $\sim 59 \%$ of the total assemblage from $t_{48}$ until the end of the experiment (Table 2). At Stn Middle, the highest proportions of BET were found in the dialysis bag treatments (Fig. 3, Table 2). At Stn Dam, BET finally became the dominant group in dialysis bag treatments at $t_{96}$ (Table 2). The phylogenetic cluster RBT065 (R-BT), which is a subgroup of BET,

treatments, bacterial abundances initially increased before decreasing again to approach initial values (Fig. 1).

In the $<5 \mu \mathrm{m}$ treatments, abundances of HNF reached very high numbers $\left(\leq 24 \times 10^{3} \mathrm{HNF} \mathrm{ml}^{-1}\right)$ at $t_{48}$ and $t_{96}$ and followed the pattern of bacterial abundance (Table 1). The only exceptions were unfiltered treatments (reservoir water), in which the abundance of HNF was efficiently controlled by cladoceran $\left(\sim 50\right.$ ind. $\left.\mathrm{l}^{-1}\right)$ grazing and thus ranged only between 0.1 and $0.7 \times 10^{3} \mathrm{HNF} \mathrm{ml}^{-1}$.

\section{Leucine incorporation}

At both stations, incorporation of leucine in the unfiltered treatments (reservoir water) was low com- clearly dominated in all treatments and generally followed the patterns described for BET during the experiment. Occasionally, the R-BT phylotypes accounted for all of the BET (Fig. 3).

Relative proportions of bacteria affiliated with the Sphingobacteria/Flavobacteria group (CF) tended to decrease from $\sim 16 \%$ to $7-12 \%$ over the course of the experiment. Occasionally, CF bacteria contributed only $\sim 3 \%$ to total abundance (Table 2 ). $\gamma$-Proteobacteria (GAM) comprised a very minor fraction of the total assemblage at both stations, accounting for only 1 to $6 \%$ of total bacteria (Table 2). The highest relative abundances of GAM were observed in the Penriched bottle treatments at Stn Dam (Table 2). Overall, between 62 and $89 \%$ of total bacteria were detected with the general probe for Bacteria (EUB, Table 2). 
Table 2. Relative abundances (\% of DAPI counts) and proportions of cells incorporating leucine (Leu+, as \% of hybridized cells) of Bacteria (EUB), $\beta$-Proteobacteria (BET), R-BT065 cluster (R-BT), Sphingobacteria/Flavobacteria group (CF), and $\gamma$-Proteobacteria (GAM) in $<0.8$ and $<5 \mu \mathrm{m}$ size fractions incubated in dialysis bags, and bottle treatments with and without $\mathrm{P}$ enrichment at $t_{0}$ and $t_{96}$. Data from unfiltered reservoir samples not shown

\begin{tabular}{|c|c|c|c|c|c|c|c|}
\hline & $\begin{array}{c}\text { Start } \\
t_{0}\end{array}$ & \multicolumn{2}{|c|}{$\begin{array}{c}\text { Dialysis bag } \\
t_{96}\end{array}$} & \multicolumn{2}{|c|}{$\begin{array}{c}\text { Bottle } \\
t_{96}\end{array}$} & \multicolumn{2}{|c|}{$\begin{array}{c}\text { Bottle }+\mathrm{P} \\
t_{96}\end{array}$} \\
\hline \multicolumn{8}{|l|}{ Stn Dam } \\
\hline$\%$ DAPI & 65.5 & 70.7 & 80.7 & 82.1 & 62.3 & 82.6 & 75.7 \\
\hline$\%$ Leu+ cells & 39.2 & 38.6 & 47.3 & 65.7 & 67 & 53.1 & 59.5 \\
\hline \multicolumn{8}{|l|}{ BET } \\
\hline$\%$ DAPI & 27 & 55.8 & 57.1 & 46 & 43.7 & 50.7 & 25.2 \\
\hline$\%$ Leu+ cells & 46.3 & 60.4 & 68.4 & 77.6 & 91.9 & 65.9 & 96.9 \\
\hline \multicolumn{8}{|l|}{ R-BT } \\
\hline$\%$ DAPI & 17.2 & 42.5 & 34.4 & 42.6 & 37.8 & 35.9 & 18.4 \\
\hline$\%$ Leu+ cells & 61.5 & 76.7 & 95.3 & 91 & 96.3 & 77 & 99.4 \\
\hline \multicolumn{8}{|l|}{ CF } \\
\hline$\%$ DAPI & 15.6 & 11.4 & 3.7 & 10.8 & 8.8 & 3.1 & 13.5 \\
\hline$\%$ Leu+ cells & 15.1 & 5.2 & 2.8 & 10.5 & 10.5 & 24.9 & 30 \\
\hline \multicolumn{8}{|l|}{ GAM } \\
\hline \% DAPI & 1.2 & 3.9 & 1.1 & 1.4 & 2.6 & 5.1 & 4.8 \\
\hline$\%$ Leu+ cells & 31.2 & 19.9 & 20.8 & 50 & 61.8 & 76.4 & 74.1 \\
\hline \multicolumn{8}{|l|}{ Stn Middle } \\
\hline$\%$ DAPI & 62.4 & 70.1 & 84.3 & 68.1 & 79.8 & 85.1 & 88.9 \\
\hline$\%$ Leu+ cells & 48.5 & 47.2 & 75.8 & 55.1 & 63.7 & 68.5 & 68.3 \\
\hline \multicolumn{8}{|l|}{ BET } \\
\hline$\%$ DAPI & 26.2 & 58.4 & 59.4 & 37.8 & 24 & 44.1 & 44.2 \\
\hline$\%$ Leu+ cells & 38.9 & 70.2 & 78.9 & 61.2 & 73.3 & 64.8 & 62.1 \\
\hline \multicolumn{8}{|l|}{ R-BT } \\
\hline \% DAPI & 11.7 & 50.4 & 49.3 & 35 & 14.6 & 37.9 & 26.8 \\
\hline$\%$ Leu+ cells & 54.2 & 81.3 & 85.5 & 71.5 & 81.2 & 70.8 & 73.8 \\
\hline \multicolumn{8}{|l|}{ CF } \\
\hline \% DAPI & 17.3 & 9.5 & 9.7 & 7.5 & 11.6 & 8 & 2.8 \\
\hline$\%$ Leu+ cells & 9.5 & 4.6 & 27.7 & 35.2 & 21.4 & 17.7 & 21.5 \\
\hline \multicolumn{8}{|l|}{ GAM } \\
\hline$\%$ DAPI & 2.5 & 5 & 4.1 & 2.7 & 5.7 & 4.8 & 3 \\
\hline$\%$ Leu+ cells & 19.9 & 27.6 & 80.9 & 59 & 27.2 & 34.7 & 37.7 \\
\hline
\end{tabular}

\section{Microautoradiography}

All phylogenetic groups of bacteria examined took up $\left[{ }^{3} \mathrm{H}\right]$-leucine (Leu, Fig. 3), but BET exhibited the most active uptake. Leu uptake markedly increased in all treatments except unfiltered reservoir samples. At $t_{96}$, the proportion of BET that assimilated Leu varied between 60 and $97 \%$ at Stn Dam and between 61 and $79 \%$ at Stn Middle (Table 2). The highest proportions of active BET were usually found in the grazer- enhanced treatments $(<5 \mu \mathrm{m}$ size fraction), but proportions were also high in bottle treatments enriched with $\mathrm{P}$, particularly at the more nutrient-limited Stn Dam. Reservoir treatments (unfiltered samples) clearly differed from the other treatments with regard to proportions of Leu-active BET over time (Fig. 3).

Leu assimilation by the members of the R-BT cluster tightly followed the trends observed for BET (Fig. 3), but the proportion of substrate-active cells within the R-BT group was even higher than that in BET (Table 2). At $t_{96}$, the proportion of Leu-active R-BT cells ranged between 71 and $99 \%$, thus comprising the most active part of the community (e.g. see Table 2 and also Fig. 6B). At Stn Dam, the highest proportions of active R-BT bacteria were found in Penriched bottle treatments with enhanced grazing pressure by HNF (Fig. 3E, Table 1), whereas substrate activity was highest in treatments incubated in dialysis bags at Stn Middle (Table 2).

Overall, bacteria from the CF group comprised the least active part of the assemblage: only 3 to $35 \%$ of total CF were detected as active cells. At Stn Dam, the increase in uptake activity was documented at $t_{96}$ in treatments enriched with P (Table 2). At Stn Middle, the uptake of Leu increased in grazer-enhanced treatments $(<5 \mu \mathrm{m}$ size fraction), and also surprisingly in the grazer-free treatment $(<0.8 \mu \mathrm{m}$ size fraction) incubated in bottles without $\mathrm{P}$ addition (Table 2). Proportions of GAM taking up Leu varied widely (20 to $81 \%$ ) among treatments (Table 2). Leu uptake increased mainly after P enrichment at Stn Dam (Table 2) but exhibited no clear trend at Stn Middle (Table 2).

The 2-way ANOVA revealed that the phylogenetic structure of bacterial assemblages was mostly influenced by incubation type, but in some cases that the effect of size-fractionation was also significant (Table 3). Significant interactions between these 2 factors were also observed. The dominant factor determining the activity of bacterial groups was type of incubation (Table 3). However, at Stn Dam, the effects of size-fractionation were significant for R-BT and GAM, whereas at Stn Middle these effects were less pronounced (Table 4). Tukey's multiple comparison tests also revealed that more significant changes in phylogenetic composition occurred at Stn Dam (Table 4). Significant differences in proportions of metabolically active cells among treatments were observed for BET and R-BT, especially at Stn Dam, and for GAM notably at Stn Middle (Table 4).

\section{Flow cytometry}

Changes in the percentage of bacteria with HNA (Fig. 4) were quite similar to those observed for bacte- 

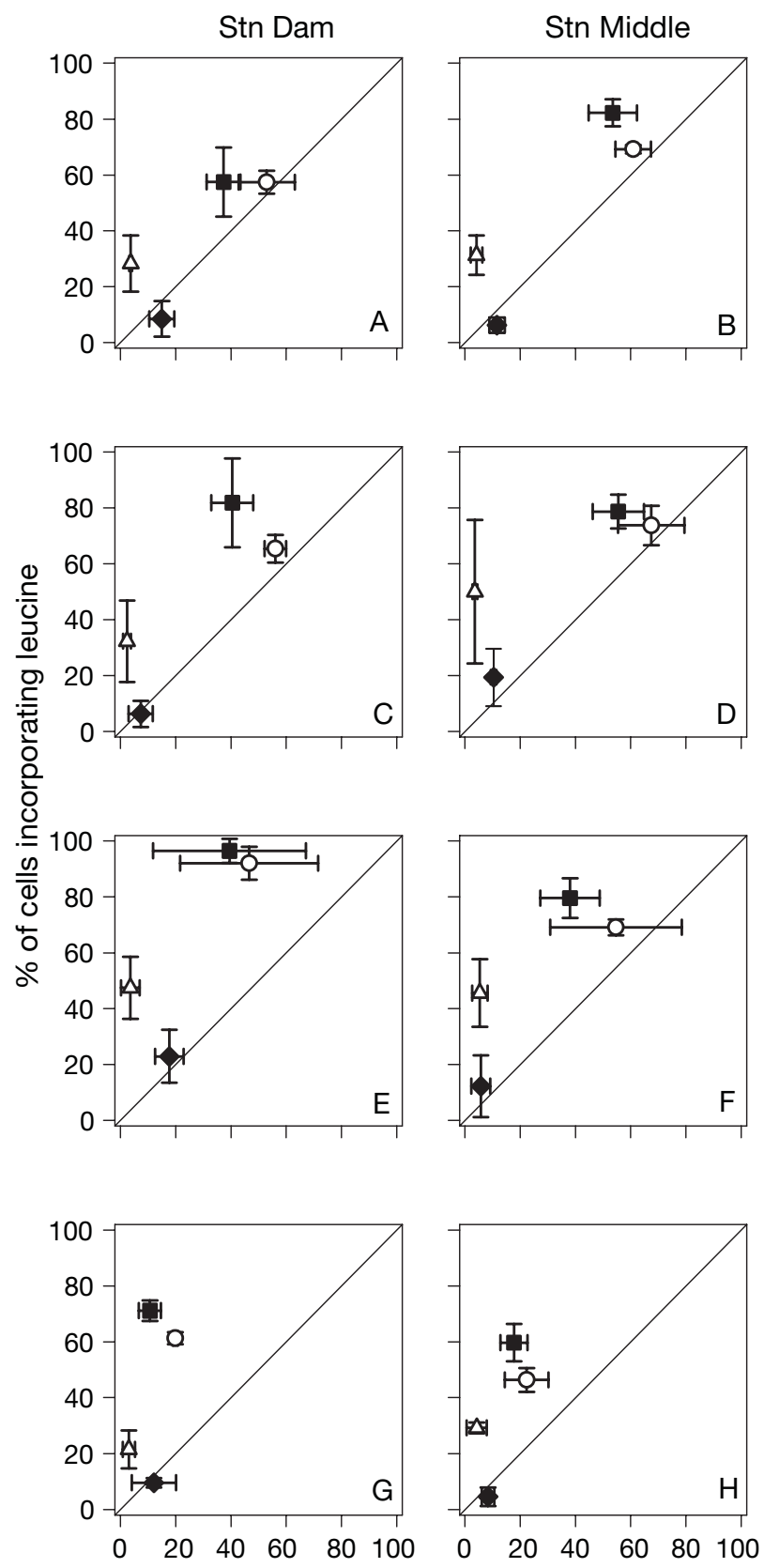

$\%$ of DAPI counts

$\begin{array}{|cccc|}-0- & \text { BET } & \Delta & \text { GAM } \\ - & \text { R-BT } & \bullet & \text { CF }\end{array}$

Fig. 3. Typical examples of mean relative proportions of different phylogenetic groups incorporating leucine (as \% of hybridized cells) plotted against mean relative abundances (as \% of DAPI counts) at $t_{48}$ and $t_{96}$. Data are means (4 replicates for each treatment). $(A, B)<0.8 \mu \mathrm{m}$ and $(C, D)<5 \mu \mathrm{m}$ size fractions incubated in dialysis bags. $(\mathrm{E}, \mathrm{F})<5 \mu \mathrm{m}$ size fraction incubated in bottles enriched with P. $(\mathrm{G}, \mathrm{H})$ Reservoir samples (unfiltered treatment). BET: $\beta$-Proteobacteria; R-BT: R-BT065 phylotypes; CF: Sphingobacteria/Flavobacteria; GAM: $\gamma$-Proteobacteria; diagonal line indicates 1:1 relationship. Error bars $= \pm \mathrm{SD}$ (except unfiltered treatments: mean deviations)
Table 3. 2-way ANOVA (F-values) testing differences in phylogenetic composition induced by size-fractionation (SF, $<0.8$ vs. $<5 \mu \mathrm{m}$ ) and incubation (I, dialysis bag, and bottle treatments with and without P enrichment) at Stns Dam and Middle at $t_{48}$ and $t_{96}$. ANOVAs were performed independently for $t_{48}$ and $t_{96}$. Values are mean of duplicates. Differences in phylogenetic composition are relative proportions ( $\%$ of DAPI counts). Leucine incorporation as $\%$ of hybridized cells. ${ }^{*} \mathrm{p}<0.05,{ }^{* *} \mathrm{p}<0.01,{ }^{* * *} \mathrm{p}<0.001$

\begin{tabular}{|c|c|c|c|c|c|c|}
\hline \multirow[t]{2}{*}{ Time } & \multicolumn{3}{|c|}{ Stn Dam } & \multicolumn{3}{|c|}{ Stn Middle } \\
\hline & $\mathrm{SF}$ & I & $\mathrm{SF} \times \mathrm{I}$ & $\mathrm{SF}$ & I & $\mathrm{SF} \times \mathrm{I}$ \\
\hline \multirow{2}{*}{\multicolumn{7}{|c|}{$\begin{array}{l}\text { Phylogenetic composition } \\
\text { BET }^{\mathrm{a}}\end{array}$}} \\
\hline & & & & & & \\
\hline$t_{48}$ & 0.44 & 0.83 & 0.79 & 1.4 & 0.72 & 1.18 \\
\hline$t_{96}$ & 0.06 & 2.54 & 1.03 & $6.6^{*}$ & 1.5 & 1.2 \\
\hline \multicolumn{7}{|l|}{ R-BT } \\
\hline$t_{48}$ & $5.89^{*}$ & 0.41 & $3.35^{*}$ & 3.38 & $9.78^{*}$ & 2.5 \\
\hline$t_{96}$ & $13.23^{*}$ & $8.56^{*}$ & 1.87 & $13.14^{*}$ & $24.42^{* *}$ & 3.39 \\
\hline \multicolumn{7}{|l|}{ CF } \\
\hline$t_{48}$ & $13.24^{* * *}$ & * $17.42^{* * *}$ & $4.33^{*}$ & 0.17 & 0.27 & $10.15^{*}$ \\
\hline$t_{96}$ & 0.05 & $28.74^{* * *}$ & 1.47 & 0.13 & $12.11^{* *}$ & $11.55^{* *}$ \\
\hline \multicolumn{7}{|l|}{ GAM } \\
\hline$t_{48}$ & 1.18 & $6.92^{*}$ & $4.09^{*}$ & 0.14 & 4.44 & 0.81 \\
\hline$t_{96}$ & 4.67 & $40.57^{* * *}$ & $16.28^{* *}$ & 0.02 & 0.16 & 2.42 \\
\hline \multicolumn{7}{|c|}{$\begin{array}{l}\text { Leucine incorporation } \\
\text { BET }^{\mathrm{a}}\end{array}$} \\
\hline$t_{48}$ & 1.99 & 0.65 & 1 & 2.09 & 1.04 & 3.69 \\
\hline$t_{96}$ & 4.22 & 2.77 & 0.67 & $21.73^{* *}$ & * 0.01 & 1.46 \\
\hline \multicolumn{7}{|l|}{ R-BT } \\
\hline$t_{48}$ & $32.79^{* * *}$ & * $39.26^{* * *}$ & $11.28^{* * *}$ & 2.08 & $6.66^{*}$ & 0.85 \\
\hline$t_{96}$ & $73.75^{* * *}$ & * $6.48^{*}$ & $8.44^{*}$ & 1.85 & $9.59^{*}$ & 3.66 \\
\hline \multicolumn{7}{|l|}{ CF } \\
\hline$t_{48}$ & 0.81 & $24.07^{* * *}$ & $3.16^{*}$ & 0.44 & $8.12^{*}$ & 1.03 \\
\hline$t_{96}$ & 0.14 & $31.1^{* * *}$ & 0.79 & $6.13^{*}$ & $36.56^{* * *}$ & ${ }^{*} 15.88^{* *}$ \\
\hline \multicolumn{7}{|l|}{ GAM } \\
\hline$t_{48}$ & $8.04^{* *}$ & $21.81^{* * *}$ & $5.1^{* *}$ & 0.68 & $17.63^{* *}$ & 1.09 \\
\hline$t_{96}$ & $16.26^{* *}$ & $158.8^{* * *}$ & $17.94^{* *}$ & 0.31 & $26.6^{* *}$ & 0.47 \\
\hline
\end{tabular}

rial abundance. Within the first $48 \mathrm{~h}$ of incubation, proportions of HNA cells increased from between 20 and $30 \%$ to between 50 and $70 \%$, depending on the treatment (unfiltered reservoir samples excluded). Then, in all treatments with enhanced bacterivory $(<5 \mu \mathrm{m}$ size fraction), the proportions of HNA cells dropped back down to initial values. At $t_{96}$, percentages of HNA cells varied between 18 and 35\%, with no clear pattern in the unfiltered reservoir treatments. Additionally, regressions between the proportions of HNA cells and relative abundances of different bacterial groups were highly significant for R-BT, BET (Fig. 5), and EUB (data not shown); no significant relationships were observed for CF and GAM (Fig. 5). 
Table 4. Results of Tukey's post-hoc test applied to pair-wise comparisons of significant differences in phylogenetic composition and incorporation of leucine among treatments (dialysis bag, and bottle treatments with and without $\mathrm{P}$ enrichment) at $t_{48}$ and $t_{96}$. Tukey's tests were performed independently for $t_{48}$ and $t_{96}$. Values are mean of duplicates. Differences in phylogenetic composition are relative proportions (\% of DAPI counts). Leucine incorporation as \% of hybridized cells. Significant differences in bold; ns: not significant

\begin{tabular}{|c|c|c|c|c|c|}
\hline \multirow{2}{*}{$\begin{array}{l}\text { Size } \\
\text { fraction }\end{array}$} & \multirow[t]{2}{*}{ Treatment } & \multicolumn{2}{|c|}{ Stn Dam } & \multicolumn{2}{|c|}{ Stn Middle } \\
\hline & & $t_{48}$ & $t_{96}$ & $t_{48}$ & $t_{96}$ \\
\hline \multicolumn{6}{|c|}{ Phylogenetic composition } \\
\hline \\
\hline \multirow[t]{3}{*}{$<0.8 \mu \mathrm{m}$} & Dial. bag vs. bottle & ns & ns & ns & $<0.05$ \\
\hline & Dial. bag vs. bottle $+P$ & $<0.05$ & $\mathrm{~ns}$ & ns & ns \\
\hline & Bottle vs. bottle + P & ns & ns & ns & ns \\
\hline \multirow[t]{3}{*}{$<5 \mu \mathrm{m}$} & Dial. bag vs. bottle & ns & $<0.05$ & ns & $<0.05$ \\
\hline & Dial. bag vs. bottle $+P$ & ns & ns & ns & ns \\
\hline & Bottle vs. bottle + P & $\mathrm{ns}$ & ns & ns & ns \\
\hline \multicolumn{6}{|c|}{ 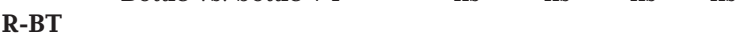 } \\
\hline \multirow[t]{3}{*}{$<0.8 \mu \mathrm{m}$} & Dial. bag vs. bottle & $<0.05$ & $<0.05$ & ns & ns \\
\hline & Dial. bag vs. bottle $+P$ & $<0.05$ & ns & ns & ns \\
\hline & Bottle vs. bottle + P & ns & $<0.05$ & ns & ns \\
\hline \multirow[t]{3}{*}{$<5 \mu \mathrm{m}$} & Dial. bag vs. bottle & $\mathrm{ns}$ & ns & ns & ns \\
\hline & Dial. bag vs. bottle $+P$ & ns & ns & ns & ns \\
\hline & Bottle vs. bottle + P & ns & ns & ns & ns \\
\hline \multicolumn{6}{|c|}{ 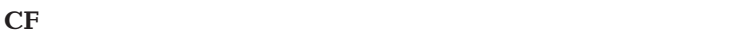 } \\
\hline \multirow[t]{3}{*}{$<0.8 \mu \mathrm{m}$} & Dial. bag vs. bottle & ns & ns & ns & ns \\
\hline & Dial. bag vs. bottle $+P$ & ns & $<0.05$ & ns & ns \\
\hline & Bottle vs. bottle $+\mathrm{P}$ & ns & $<0.05$ & $<0.05$ & ns \\
\hline \multirow[t]{3}{*}{$<5 \mu \mathrm{m}$} & Dial. bag vs. bottle & ns & ns & ns & ns \\
\hline & Dial. bag vs. bottle $+P$ & $<0.05$ & $<0.05$ & $\mathrm{~ns}$ & $<0.05$ \\
\hline & Bottle vs. bottle + P & $<0.05$ & ns & ns & $<0.05$ \\
\hline \multicolumn{6}{|l|}{ GAM } \\
\hline \multirow[t]{3}{*}{$<0.8 \mu \mathrm{m}$} & Dial. bag vs. bottle & ns & $<0.05$ & ns & ns \\
\hline & Dial. bag vs. bottle $+P$ & $\mathrm{~ns}$ & ns & ns & ns \\
\hline & Bottle vs. bottle + P & $\mathrm{ns}$ & $<0.05$ & ns & ns \\
\hline$<5 \mu \mathrm{m}$ & Dial. bag vs. bottle & ns & ns & ns & ns \\
\hline & Dial. bag vs. bottle $+P$ & ns & $<0.05$ & ns & ns \\
\hline & Bottle vs. bottle + P & ns & ns & ns & ns \\
\hline Leucine $\mathrm{i}$ & ncorporation & & & & \\
\hline BET & & & & & \\
\hline$<0.8 \mu \mathrm{m}$ & Dial. bag vs. bottle & $<0.05$ & $<0.05$ & ns & $<0.05$ \\
\hline & Dial. bag vs. bottle $+\mathrm{P}$ & $<0.01$ & ns & ns & ns \\
\hline & Bottle vs. bottle + P & ns & ns & ns & ns \\
\hline$<5 \mu \mathrm{m}$ & Dial. bag vs. bottle & $<0.05$ & $<0.05$ & ns & ns \\
\hline & Dial. bag vs. bottle $+P$ & $<0.05$ & $<0.05$ & ns & ns \\
\hline & Bottle vs. bottle $+\mathrm{P}$ & ns & ns & ns & ns \\
\hline R-BT & & & & & \\
\hline$<0.8 \mu \mathrm{m}$ & Dial. bag vs. bottle & $<0.05$ & $<0.05$ & ns & ns \\
\hline & Dial. bag vs. bottle $+P$ & $<0.05$ & ns & ns & ns \\
\hline & Bottle vs. bottle + P & ns & $<0.05$ & ns & ns \\
\hline$<5 \mu \mathrm{m}$ & Dial. bag vs. bottle & ns & ns & ns & ns \\
\hline & Dial. bag vs. bottle $+P$ & $\mathrm{~ns}$ & ns & $<0.05$ & ns \\
\hline & Bottle vs. bottle + P & ns & ns & $<0.05$ & ns \\
\hline CF & & & & & \\
\hline$<0.8 \mu \mathrm{m}$ & Dial. bag vs. bottle & ns & ns & ns & $<0.01$ \\
\hline & Dial. bag vs. bottle $+P$ & $\mathrm{~ns}$ & ns & ns & ns \\
\hline & Bottle vs. bottle + P & $\mathrm{ns}$ & $\mathrm{ns}$ & $\mathrm{ns}$ & $<0.05$ \\
\hline$<5 \mu \mathrm{m}$ & Dial. bag vs. bottle & ns & ns & ns & ns \\
\hline & Dial. bag vs. bottle $+P$ & ns & $<0.01$ & ns & ns \\
\hline & Bottle vs. bottle + P & ns & $<0.05$ & ns & ns \\
\hline GAM & & & & & \\
\hline$<0.8 \mu \mathrm{m}$ & Dial. bag vs. bottle & ns & ns & ns & $<0.01$ \\
\hline & Dial. bag vs. bottle $+P$ & $\mathrm{~ns}$ & ns & ns & ns \\
\hline & Bottle vs. bottle + P & ns & ns & ns & $<0.01$ \\
\hline$<5 \mu \mathrm{m}$ & Dial. bag vs. bottle & ns & $<0.05$ & ns & $<0.01$ \\
\hline & Dial. bag vs. bottle $+P$ & $\mathrm{~ns}$ & $<0.01$ & $<0.05$ & $<0.01$ \\
\hline & Bottle vs. bottle + P & ns & ns & $<0.05$ & ns \\
\hline
\end{tabular}

\section{DISCUSSION}

Abundances in the grazer-free $(<0.8 \mu \mathrm{m}$ size fraction) dialysis bag treatments penetrable to nutrients continuously increased until the end of incubation period. This increase contrasted with incubations in glass bottles without $\mathrm{P}$ enrichment, in which bacteria seemed to be limited by resources, even at the relatively nutrient-rich Stn Middle. Moreover, P enrichment stimulated bacterial growth at the nutrient-poor Stn Dam, whereas it had no marked effect on bacterial abundance at Stn Middle. The effects of P enrichment in bottle incubations were likely overwhelmed by the disconnection of bacteria from ongoing resource recycling in the reservoir. Thus, the bacterial assemblage from Stn Middle might have been limited by $\mathrm{C}$ resources. The results of bacterial leucine incorporation correspond with this. At Stn Middle, the highest rates of leucine incorporation were observed in dialysis bag treatments, whereas at Stn Dam highest rates were usually observed in the P-enriched bottle treatments. Overall, it is likely that bacterial assemblages were mainly influenced by bottom-up manipulations (Table 3).

In some treatments (e.g. at $t_{0}$ ) we detected only 62 to $65 \%$ of EUB using the EUB338 probe. We would have probably detected larger proportions of EUB using a mixture of EUBI-III probes (Daims et al. 1999), but this study focused on the active leucine incorporation of specific bacterial groups rather than the relative abundances and activities of the whole EUB domain.

Most of the parameters measured in the unfiltered treatments (reservoir samples) differed markedly from other treatments. No trends were observed in bacterial abundance (Fig. 1) and incorporation of leucine (Fig. 2), likely due to balanced growth and loss rates established between the bacterial assemblage and its grazers. Moreover, high abundances ( 50 ind. $\mathrm{l}^{-1}$ ) of large metazooplankton predators present at both stations during the time of our experiment (clear-water phase), namely Daphnia galeata, suppressed the grazing effect of HNF and the potential development of bacterial grazing-resistant morphotypes (e.g. Degans et al. 2002). Additionally, only minor changes in relative abundances and proportions of cells taking up leucine in unfiltered treatments were observed (Fig. 3).

\section{Effects of resources and grazers on bacterial activity}

The largest shifts in relative abundances and proportions of cells incorporating leucine occurred within the 2 most abundant phylogenetic groups, i.e. BET and R-BT bacteria. Relative abundances of BET and R-BT bacteria substantially decreased when high abun- 


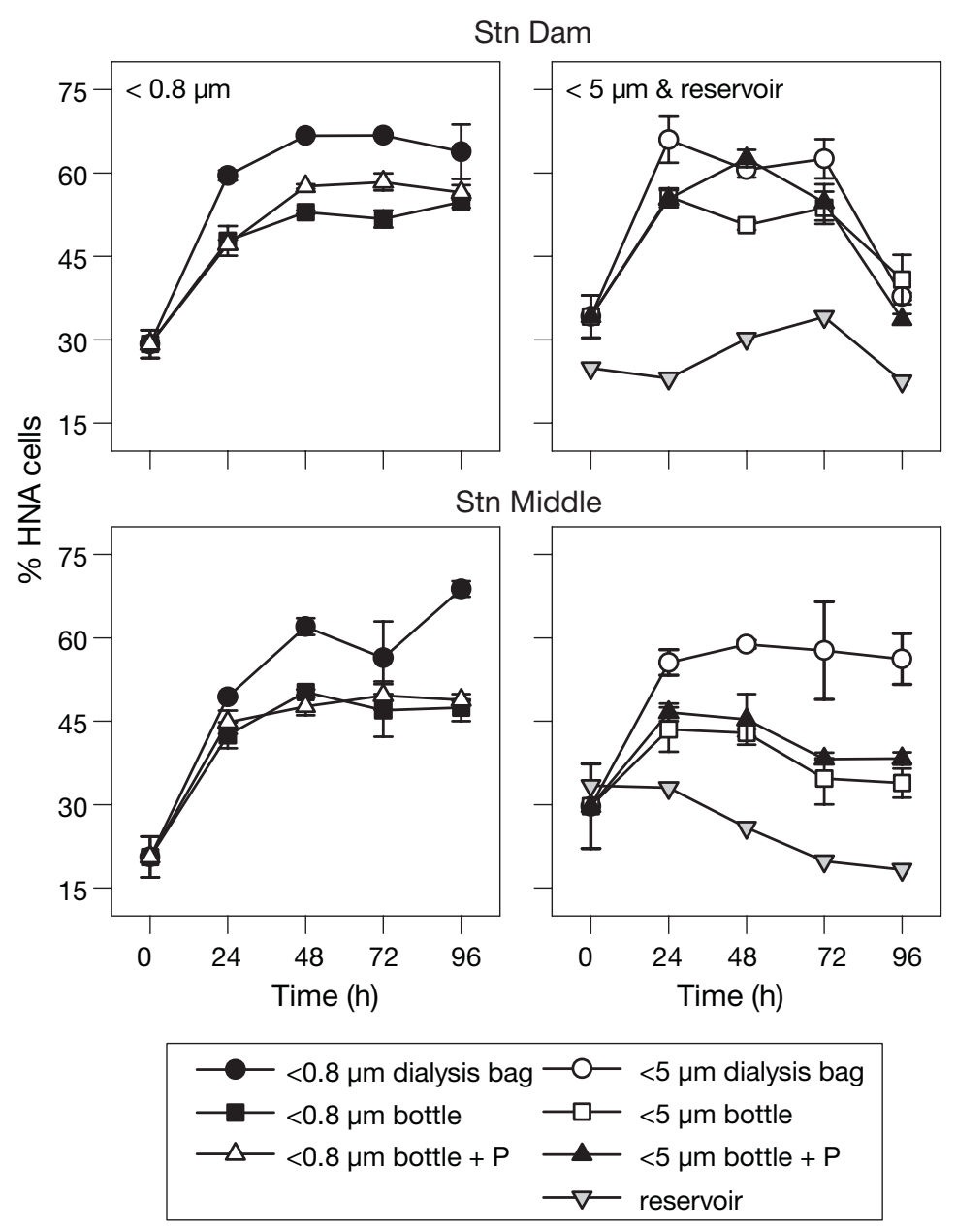

Fig. 4. Temporal changes in proportions of bacteria with high nucleic acid content (HNA) in different treatments (dialysis bag, bottle treatments with and without $\mathrm{P}$ enrichment, unfiltered reservoir samples) at both experimental sites (Stns Dam and Middle). Values are mean of duplicates. Error bars $= \pm \mathrm{SD}$

dances of HNF were present, suggesting that these phylotypes were the major food resource for HNF. Analysis of the food vacuoles of HNF by CARD-FISH in a field manipulation experiment revealed that HNF grazed more on R-BT bacteria than on other bacterial groups (Jezbera et al. 2005). In general, fast-growing bacteria tend to have a larger cell volume (e.g. Servais et al. 1999) and thus these cells may also be preferentially grazed. However, no marked differences between cell volume of R-BT bacteria and average bacterioplankton were observed, despite the fact that fast-growing R-BT cells were quite vulnerable to grazers (Jezbera et al. 2005). Predator-induced specific enrichment of certain phylotypes was also reported from a continuous culture system (Actinobacteria, Pernthaler et al. 2001) as well as for marine coastal plankton (GAM, Beardsley et al. 2003). Decreasing proportions of R-BT phylotypes under increasing protistan grazing pressure are consistent with previous studies conducted in the Římov reservoir (Jezbera et al. 2003, Šimek et al. 2003, 2005), which determined that R-BT bacteria usually dominate when grazers are removed but become markedly affected at very high levels of bacterivory. Interestingly, the largest decline in the relative abundance of R-BT occurred in the Penriched treatments, indicating that these phylotypes are well adapted to and highly competitive under P-limited conditions.

Proportions of BET, especially R-BT, actively assimilating leucine were usually considerably higher in treatments with enhanced grazing $(<5 \mu \mathrm{m}$ size fraction). Apparently, the increased bacterivory and subsequent recycling of resources stimulated the metabolic activity and growth of BET and R-BT bacteria.

The relative proportion of HNA bacteria has been proposed to be an indicator of bacterial growth and activity (e.g. Servais et al. 1999). It has also been documented that most leucine incorporation is performed by HNA bacteria (Lebaron et al. 2001, Servais et al. 2003). The relationship between proportions of HNA cells and R-BT bacteria was highly significant (Fig. 5), thus confirming the finding of a previous study (Šimek et al. 2005). An almost identical relationship was found between HNA cells and BET, but when R-BT bacteria were excluded from the analysis the correlation was no longer significant $\left(\mathrm{R}^{2}<0.01, \mathrm{p}=0.61, \mathrm{n}=34\right.$, data not shown), indicating the key role of the fastgrowing members of the R-BT cluster within the phylogenetically broad BET group. In addition, proportions of HNA cells markedly decreased in treatments with enhanced grazing ( $<5 \mu \mathrm{m}$ size fraction), suggesting that bacterivores preferably eliminated more active cells within the assemblage (Fig. 4, in particular Stn Dam), as was reported previously (e.g. del Giorgio et al. 1996a). Contrary to these results, the R-BT cluster showed a remarkable increase in physiologic activity and was the only group with a higher proportion of active cells under extreme levels of bacterivory, such as those detected at $t_{96}$ in the $<5 \mu \mathrm{m}$ size fractions (data not shown). Neither GAM nor CF bacteria exhibited a clear trend with regard to proportions of HNA cells (Fig. 5), suggesting that these groups were outcompeted by R-BT phylotypes with increased activity of the assemblage. 

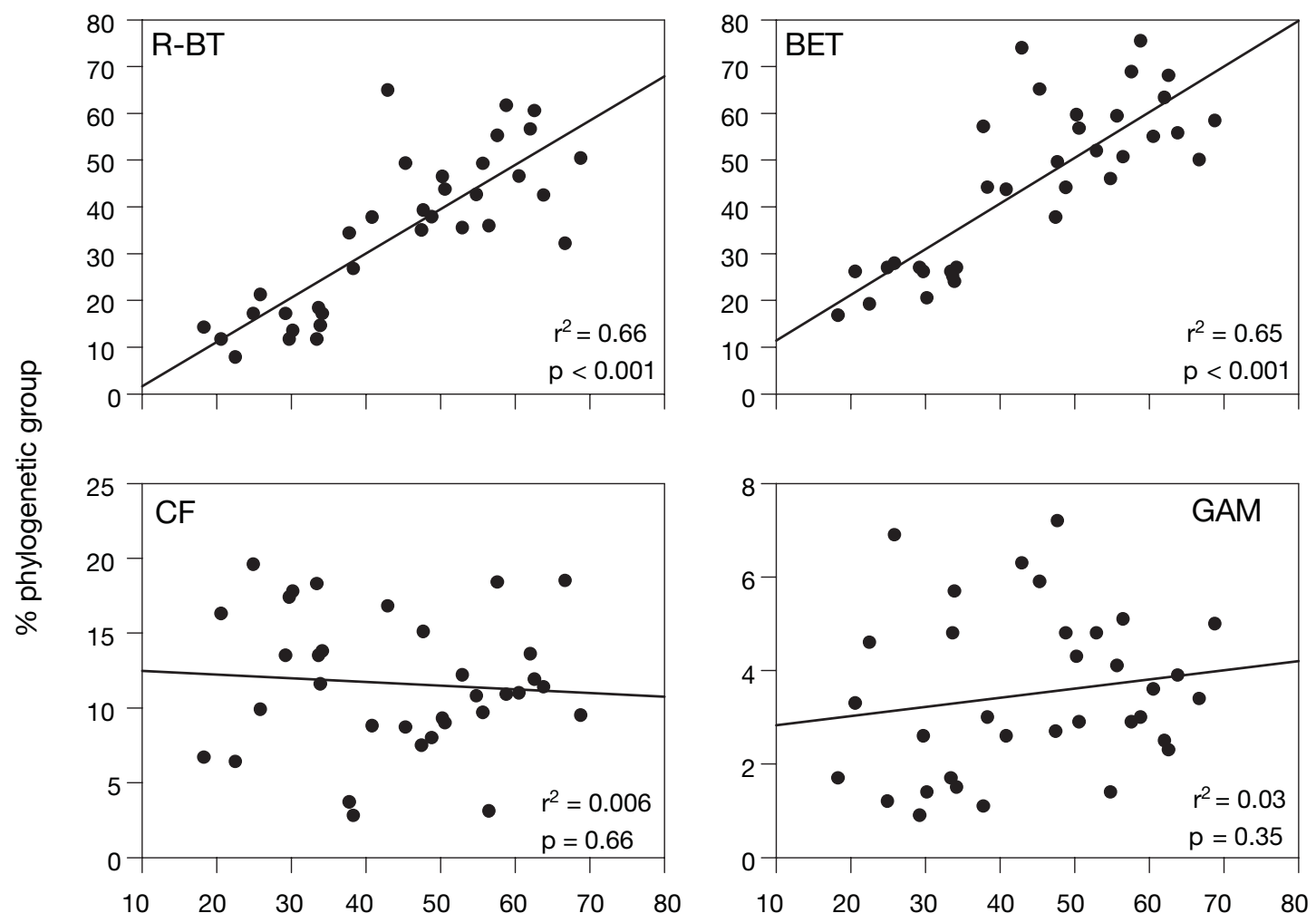

$\%$ HNA cells

Fig. 5. Regression relationships between \% HNA cells and relative proportions of R-BT, BET, CF, and GAM. Each point represents mean of duplicates. For all analyses, $\mathrm{n}=34$

Furthermore, it has been documented that, in many aquatic systems, HNA cells have significantly higher specific activity than bacteria with low nucleic acid content (LNA) (Servais et al. 2003); however, Longnecker et al. (2005) suggested recently that LNA bacteria may not differ from HNA cells in terms of specific rates of substrate incorporation in marine systems and may also significantly contribute to bacterial metabolism. Nevertheless, HNA bacteria numerically dominated in our experiment (Fig. 4), and thus it is likely that HNA cells were largely responsible for bacterial activity and production. Moreover, freshwater ecosystems may substantially differ from marine ecosystems in terms of bacterial composition, proportions and metabolic activities of HNA cells.

Members of BET, particularly the R-BT phylotypes, were able to maintain very high levels of leucine assimilation even under substantially different conditions. This finding suggests that R-BT bacteria, representing the vast majority of BET in most treatments, play a key role in overall activity not only within BET but also within the entire bacterial assemblage, as previously proposed (Šimek et al. 2005; see Table 2 and Fig. 6). Members of R-BT also expressed the smallest variation in growth rates among 8 manipulation experiments conducted in the Rímov reservoir (K. Šimek unpubl. data). Additionally, BET and R-BT bacteria form the major component of bacterial assemblages in the surface layer of the Rímov reservoir, both seasonally and spatially (e.g. Šimek et al. 2001, 2003, Horňák et al. 2005). These results indicate that R-BT phylotypes adapt possible opportunistic strategies, showing rapid responses to differing environmental conditions including adaptations to sudden changes in resource availability. Similar results that suggested the existence of such opportunistic strategies were previously documented for the $\beta$-II lineage from the humic lake Große Fukskuhle (Burkert et al. 2003). Bearing in mind that existing data were obtained from very distinct environments (the Rímov reservoir cf. Große Fukskuhle), it appears that at least 2 phylogenetically distinct lineages within BET share similar ecological characteristics.

Generally, very low incorporation rates of leucine together with decreased relative abundances of the CF group were observed in most treatments (Table 2), suggesting that $\mathrm{CF}$ contributed little to bulk biomass production. It is known that CF bacteria are especially 

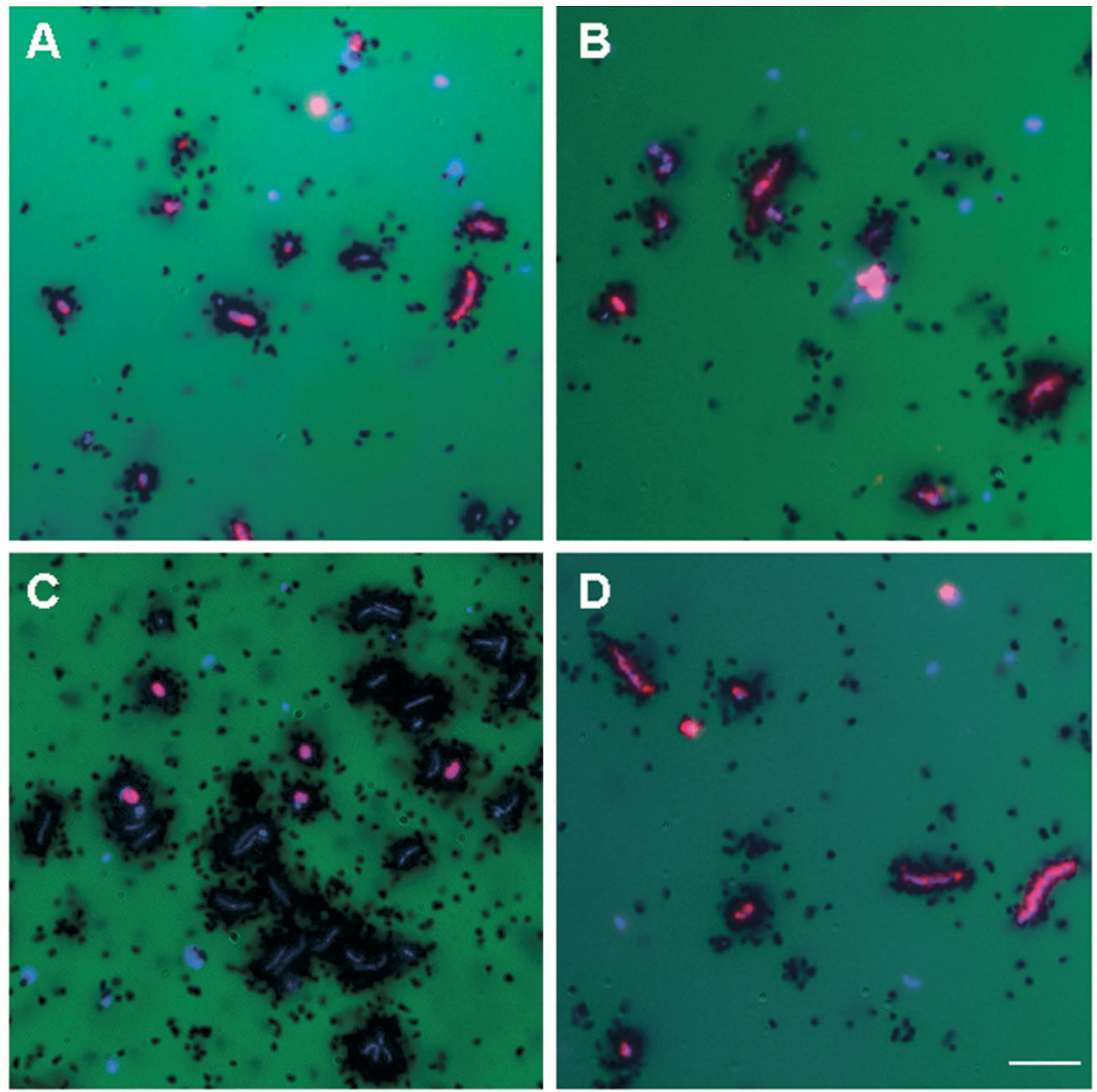

Fig. 6. Bacteria assayed by CARD-FISH combined with microautoradiography. Hybridized cells are in red, DAPI-stained cells in blue. Active leucine incorporation is indicated by dark silver grains surrounding cells. (A) BET42a-positive cells in $<5 \mu \mathrm{m}$ dialysis bag treatment incubated at Stn Dam. (B) R-BT065 phylotypes in the same treatment. (C) GAM42a bacteria in $<5 \mu \mathrm{m}$ bottle treatment enriched with $\mathrm{P}$ at Stn Middle. (D) EUB338 cells in reservoir (unfiltered) samples from Stn Middle. All micrographs taken at $t_{96}$. Scale bar (for A-D) $=5 \mu \mathrm{m}$

prominent in the utilization of various biopolymers such as cellulose, chitin, and pectin (Reichenbach \& Dworkin 1991), and may thus be less efficient in the uptake or even unable to incorporate low molecular compounds such as amino acids (Cottrell \& Kirchman 2000 ) and other compounds produced by e.g. phytoplankton (e.g. Obernosterer \& Herndl 1995). Nevertheless, even the less-active CF phylotypes exhibited relatively higher rates of leucine assimilation after $\mathrm{P}$ addition. It seems that $\mathrm{CF}$ also profited from $\mathrm{P}$ enrichment but with a pronounced 'lag-phase', perhaps needed for metabolic adaptation or resulting from a community shift within the CF group.

Although GAM was overall the least abundant group within the assemblage, GAM belonged to the metabolically highly active part of the community
(Figs. 3 \& 6). P enrichment induced a steep increase in leucine assimilation by GAM (Table 2), suggesting that GAM bacteria are adapted to high nutrient concentrations, as reported previously (Zavarzin et al. 1991). This rapid response to $P$ enrichment implies that GAM bacteria may maintain a high growth potential even under inappropriate environmental conditions, which is rapidly triggered by $\mathrm{P}$ amendment. Similar findings were reported for several members of GAM from North Sea bacterioplankton exposed to nutrient enrichment (Eilers et al. 2000). Interestingly, high levels of leucine uptake were also recorded in incubations performed in glass bottles without $\mathrm{P}$ enrichment, indicating that GAM bacteria could profit from marked changes in treatment-specific resource availability. 
One should take into account that all data on relative abundances and proportions of active cells were obtained from a specific period of the year (clear-water phase) and might be considerably modified by the succession of plankton assemblages. Similarly, the use of different types of substrate and incubation chambers might reveal markedly different responses of bacteria to experimental manipulations. Dialysis bags are easily penetrable to low molecular weight compounds (12 to $16 \mathrm{kDa}$ ), but may not be penetrable to some high molecular weight compounds, such as humic substances present in the Římov reservoir, which may partially alter resource availability for microorganisms. Additionally, proportions of metabolically active cells were determined from the incorporation of radiolabelled leucine at a trace concentration. One might argue that the use of higher leucine concentrations would have allowed us to observe higher proportions of active cells, but we intended to monitor actual bacterial metabolic activities rather than potential activities determined from a saturation approach.

Overall, in terms of relative abundance and metabolic activity under different levels of resource availability and predation pressure, the bacterioplankton assemblage was dominated by BET and R-BT bacteria. The small cluster of R-BT bacteria played a key role in the overall activity and production of the whole assemblage. Moreover, the R-BT cells adapted quickly to new environmental conditions and experimental treatments, indicating a potential opportunistic strategy of these phylotypes. The CF group generally exhibited very low proportions of cells active in leucine incorporation, and thus contributed very little to bulk production. In contrast, GAM bacteria were overall the least abundant but a highly active group within the assemblage, very responsive to $\mathrm{P}$ enrichment, bringing attention to the high growth potential of these bacteria.

Acknowledgements. We thank M. Sed'a for zooplankton data, M. Mašín and J. Vrba for help with sampling, and L. Alonso, M. Vila, E. Teira, and T. Reinthaler for the introduction to microautoradiography. We also acknowledge S. Smrčková and R. Malá for technical assistance. We thank D. Kirchman for English corrections and 3 anonymous reviewers for valuable suggestions and helpful comments. This study was supported by the Grant Agency of the Czech Republic (research grant 206/05/0007 awarded to K.Š., and FRVŠ grant 1062/2004 awarded to K.H.), and by the Academy of Sciences of the Czech Republic project AVOZ 60170517.

\section{LITERATURE CITED}

Amann R, Ludwig W, Schleifer KH (1995) Phylogenetic identification and in situ detection of individual microbial cells without cultivation. Microbiol Rev 59:143-159
Azam F, Fenchel T, Field JG, Gray JS, Meyerreil JA, Thingstad F (1983) The ecological role of water-column microbes in the sea. Mar Ecol Prog Ser 10:257-263

Beardsley C, Pernthaler J, Wosniok W, Amann R (2003) Are readily culturable bacteria in coastal North Sea waters suppressed by selective grazing mortality? Appl Environ Microbiol 69:2624-2630

Burkert U, Warnecke F, Babenzien D, Zwirnmann E, Pernthaler J (2003) Members of a readily enriched $\beta$-Proteobacterial clade are common in surface waters of a humic lake. Appl Environ Microbiol 69:6550-6559

Chrzanowski TH, Šimek K (1990) Prey-size selection by freshwater flagellated protozoa. Limnol Oceanogr 35: 1429-1436

Cottrell MT, Kirchman DL (2000) Natural assemblages of marine proteobacteria and members of the CytophagaFlavobacter cluster consuming low- and high-molecularweight dissolved organic matter. Appl Environ Microbiol 66:1692-1697

Daims H, Bruhl A, Amann R, Schleifer KH, Wagner M (1999) The domain-specific probe EUB338 is insufficient for the detection of all Bacteria: development and evaluation of a more comprehensive probe set. Syst Appl Microbiol 22: $434-444$

Degans H, Zollner E, Van der Gucht K, De Meester L, Jürgens K (2002) Rapid Daphnia-mediated changes in microbial community structure: an experimental study. FEMS Microbiol Ecol 42:137-149

del Giorgio PA, Gasol JM, Vaqué D, Mura P, Agustí S, Duarte CM (1996a) Bacterioplankton community structure: protist control net production and the proportion of active bacteria in a coastal marine community. Limnol Oceanogr 41: 1169-1179

del Giorgio PA, Bird DF, Prairie YT, Planas D (1996b) Flow cytometric determination of bacterial abundance in lake plankton with the green nucleic acid stain SYTO 13. Limnol Oceanogr 41:783-789

Eilers H, Pernthaler J, Glöckner FO, Amann R (2000) Culturability and in situ abundance of pelagic bacteria from the North Sea. Appl Environ Microbiol 66:3044-3051

Fuhrman J (1999) Marine viruses and their biogeochemical and ecological effects. Nature 399:541-548

Gasol JM, del Giorgio PA (2000) Using flow cytometry for counting natural planktonic bacteria and understanding the structure of planktonic bacterial communities. Sci Mar 64:197-224

Gasol JM, Zweifel UL, Peters F, Fuhrman JA, Hagström ^̊ (1999) Significance of size and nucleic acid content heterogeneity as measured by flow cytometry in natural planktonic bacteria. Appl Environ Microbiol 65: 4475-4483

Hahn MW, Höfle MG (2001) Grazing of protozoa and its effect on populations of aquatic bacteria. FEMS Microbiol Ecol 35:113-121

Horňák K, Mašín M, Jezbera J, Bettarel Y, Nedoma J, SimeNgando T, Šimek K (2005) Effects of decreased resource availability, protozoan grazing and viral impact on a structure of bacterioplankton assemblage in a canyon-shaped reservoir. FEMS Microbiol Ecol 52:315-327

Ito T, Nielsen JL, Okabe S, Watanabe Y, Nielsen PH (2002) Phylogenetic identification and substrate uptake patterns of sulfate-reducing bacteria inhabiting an oxic-anoxic sewer biofilm determined by combining microautoradiography and fluorescent in situ hybridization. Appl Environ Microbiol 68:356-364

Jezbera J, Nedoma J, Šimek K (2003) Longitudinal changes in protistan bacterivory and bacterial production in two 
canyon-shaped reservoirs of different trophic status. Hydrobiologia 504:115-130

Jezbera J, Horňák K, Šimek K (2005) Food selection by bacterivorous protists: insight from the analysis of the food vacuole content by means of fluorescence in situ hybridization. FEMS Microbiol Ecol 52:351-363

Jürgens K, Güde H (1994) The potential importance of grazing-resistant bacteria in planktonic systems. Mar Ecol Prog Ser 112:169-188

Jürgens K, Matz C (2002) Predation as a shaping force for the phenotypic and genotypic composition of planktonic bacteria. Antonie Leeuwenhoek 81:413-434

Karner M, Fuhrman J (1997) Determination of active marine bacterioplankton: a comparison of universal 16S rRNA probes, autoradiography, and nucleoid staining. Appl Environ Microbiol 63:1208-1213

Kirchman DL (2002) The ecology of Cytophaga-Flavobacteria in aquatic environments. FEMS Microbiol Ecol 39:91-100

Langenheder S, Jürgens K (2001) Regulation of bacterial biomass and community structure by metazoan and protozoan predation. Limnol Oceanogr 46:121-134

Lebaron P, Servais P, Troussellier M, Courties C and 7 others (2001) Microbial community dynamics in Mediterranean nutrient-enriched seawater mesocosms: changes in abundances, activity and composition. FEMS Microbiol Ecol 34: 255-266

Lee N, Nielsen PH, Andreasen KH, Juretschko S, Nielsen JL, Schleifer KH, Wagner M (1999) Combination of fluorescent in situ hybridization and microautoradiography-a new tool for structure-function analyses in microbial ecology. Appl Environ Microbiol 65:1289-1297

Longnecker K, Sher BF, Sherr EB (2005) Activity and phylogenetic diversity of bacterial cells with high nucleic and low nucleic acid content and electron transport system activity in an upwelling ecosystem. Appl Environ Microbiol 71:7737-7749

Obernosterer I, Herndl GJ (1995) Phytoplankton extracellular release and bacterial-growth-dependence on the inorganic N-P ratio. Mar Ecol Prog Ser 116:247-257

Ouverney CC, Fuhrman JA (2000) Marine planktonic archaea take up amino acids. Appl Environ Microbiol 66: 4829-4833

Pace ML, Cole JJ (1996) Regulation of bacteria by resources and predation tested in whole-lake experiments. Limnol Oceanogr 41:1448-1460

Pernthaler J, Amann R (2005) Fate of heterotrophic microbes in pelagic habitats: focus on populations. Microbiol Mol Biol Rev 69:440-461

Pernthaler J, Posch T, Šimek K, Vrba J and 5 others (2001) Predator-specific enrichment of actinobacteria from a cosmopolitan freshwater clade in mixed continuous culture. Appl Environ Microbiol 67:2145-2155

Reichenbach H, Dworkin M (1991) The order Cytophagales. In: Balows A, Truper HG, Dworkin M, Harder W, Schleifer KH (eds) The Prokaryotes. Springer Verlag, New York, p 356-379

Sanders RW, Porter KG, Bennet SJ, DeBiase AE (1989) Seasonal patterns of bacterivory by flagellates, ciliates, rotifers, and cladocerans in a freshwater planktonic community. Limnol Oceanogr 34:673-687

Editorial responsibility: Klaus Jürgens, Rostock, Germany
Sekar R, Pernthaler A, Pernthaler J, Warnecke F, Posch T, Amann R (2003) An improved protocol for quantification of freshwater Actinobacteria by fluorescence in situ hybridization. Appl Environ Microbiol 69:2928-2935

Servais P, Courties C, Lebaron P, Troussellier M (1999) Coupling bacterial activity measurements with cell sorting and flow cytometry. Microb Ecol 38:180-189

Servais P, Casamayor EO, Courties C, Catala P, Parthuisot N, Lebaron P (2003) Activity and diversity of bacterial cells with high and low nucleic acid content. Aquat Microb Ecol 33:41-51

Sherr EB, Sherr BF (1993) Protistan grazing rates via uptake of fluorescently labelled prey. In: Kemp P, Sherr BF, Sherr EB, Cole J (eds) Handbook of methods in aquatic microbial ecology. Lewis, Boca Raton, FL, p 695-701

Šimek K, Vrba J, Pernthaler J, Posch T, Hartman P, Nedoma J, Psenner R (1997) Morphological and compositional shifts in an experimental bacterial community influenced by protists with contrasting feeding modes. Appl Environ Microbiol 63:587-595

Šimek K, Pernthaler J, Weinbauer MG, Horňák K, Dolan JR, Nedoma J, Mašín M, Amann R (2001) Changes in bacterial community composition and dynamics and viral mortality rates associated with enhanced flagellate grazing in a mesoeutrophic reservoir. Appl Environ Microbiol 67: $2723-2733$

Šimek K, Horňák K, Mašín M, Christaki U, Nedoma J, Wienbauer MG, Dolan JR (2003) Comparing the effects of resource enrichment and grazing on a bacterioplankton community of a meso-eutrophic reservoir. Aquat Microb Ecol 31:123-135

Šimek K, Horňák K, Jezbera J, Mašín M, Nedoma J, Gasol JM, Schauer M (2005) Influence of top-down and bottom-up manipulations on the R-BT065 subcluster of $\beta$-Proteobacteria, an abundant group in bacterioplankton of a freshwater reservoir. Appl Environ Microbiol 71:2381-2390

Teira E, Reinthaler T, Pernthaler A, Pernthaler J, Herndl GJ (2004) Combining catalyzed reporter deposition-fluorescence in situ hybridization and microautoradiography to detect substrate utilization by bacteria and archaea in the deep ocean. Appl Environ Microbiol 70:4411-4414

Thingstad TF, Lignell R (1997) Theoretical models for the control of bacterial growth rate, abundance, diversity and carbon demand. Aquat Microb Ecol 19:19-27

Troussellier M, Schafer H, Batailler N, Bernard L and 5 others (2002) Bacterial activity and genetic richness along an estuarine gradient (Rhone River plume, France). Aquat Microb Ecol 28:13-24

Vrede K (1999) Effects of inorganic nutrients and zooplankton on the growth of heterotrophic bacterioplankton-enclosure experiments in an oligotrophic clearwater lake. Aquat Microb Ecol 18:133-144

Zavarzin GA, Stackebrandt E, Murray RGE (1991) A correlation of phylogenetic diversity in the proteobacteria with the influences of ecological forces. Can J Microbiol 37: $1-6$

Zwart G, Crump BC, Kamst-van Agsterveld MP, Hagen F, Han SK (2002) Typical freshwater bacteria: an analysis of available 16S rRNA gene sequences from plankton of lakes and rivers. Aquat Microb Ecol 28:141-155

Submitted: March 28, 2006; Accepted: September 8, 2006 Proofs received from author(s): November 22, 2006 